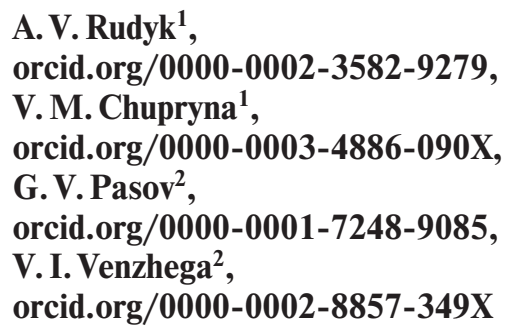

1 - State Research Institute for Testing and Certification of Weapons and Military Equipment, Chernihiv, Ukraine, e-mail: andrei.rudik@gmail.com

2 - National University "Chernihiv Polytechnic", Chernihiv, Ukraine

\title{
METHODS FOR DETERMINING THE EFFICIENCY OF THE GRINDING PROCESS
}

Purpose. To create a method for using a new indicator of the intensity of cutting modes which will reduce the amount of reference information on the methods of both grinding and machining with a blade tool.

Methodology. Analytical research.

Findings. A new local indicator of the intensity of cutting modes, which has a clear physical meaning - the thickness of the cut - is proposed. It is determined by the projection of the feed rate of the part in the direction of the normal to the surface of the tool. The indicator can be applied to various kinematics of processes of grinding of details. The technique is suitable for abrasive and blade tools. Thanks to the new indicator, the amount of reference information is reduced.

Originality. As an indicator of processing intensity instead of the integrated indicator of specific productivity it is offered to use the local one - a projection of speed of relative movement of giving in the normal direction. The indicator has a clear physical meaning and determines the thickness of the cut for a given cutting speed. It allows considering all kinematic components and contains the full information on loading of a site of a profile within contact, allows distinguishing passing and counter processing which depend on a mutual direction of vectors of speed of cutting and circular giving. The relationship between the projection of the relative velocity in the normal direction, the specific productivity and the length of contact is found.

Practical value. The indicator of grinding efficiency modes for methods of longitudinal and expressive machining of parts is determined. It gives an opportunity to unify the data of tables of modes, to use calculations both for various methods for grinding, and processing by the blade tool. A method for determining the grinding efficiency index with an oriented tool, where stability acts as an objective function, is proposed. Productivity is a balance condition, and surface roughness determines the boundary condition. The definition of extreme values of intensity is given. Separate indicators of the mode both for the created new technique and the one used on the equipment of the known German firm are defined.

Keywords: grinding modes, specific productivity, normal speed, angular size of contact, stability

Introduction. Rational assignment of modes and the choice of method for grinding allow increasing the treatment efficiency [1], reducing the production cost, machine time [2], the tool wear and the energy consumption of the process [3].

Methods for round longitudinal and cut grinding for which, as a rule, the modes are given separately, are most widely covered in the literature $[1,2]$. However, the influence of some movements, for example, the longitudinal feed and cutting speed in grinding, is usually neglected.

Specialists of the company "Junkermaschinen" (Germany) [4] created a new method for effective depth grinding tool with an angular orientation on base of machines "Quickpoint 1000", "Quickpoint 3000”, “4000 Quickpoint”. Deep multi-pass treatment is carried out on the periphery of the returned tool. The method allows increasing both the productivity by increasing the size of the contact area, much of which is made on the end, and the quality when obtaining the surface roughness in the form of a grid. In addition, it combines rough, half-finish and finish processing in one process with the distribution of plots along the profile of the tool of a large diameter. The final quality is obtained only by a short section within the forming point.

Ukrainian scientists have created a similar method $[5,6]$. Mode indicators of the grinding process in the works are not given.

The authors established new methods for grinding rollers and the fallen stepped surfaces [7]. These methods can be performed by the conical surface of the cup-shaped tool.

However, the choice of the operating parameters of the treatment methods shown effective in the technical literature are not given.

The question arises: is it possible to conduct a synthesis of recommendations for the selection of modes for grinding [2] and blade operations, taking into account all kinematic components (the influence of which is neglected) and the relative orientation of the tool $[8,9]$.

Literature review. Works by a number of scientists are devoted to the choice of grinding modes $[2,3,10]$. The information is also contained in technological reference books, operational maps, empirical dependences in the form of a power function on a given rational stability of the tool and processing parameters [7].

In [2], the influence on the specific productivity of the contact length between the circle and the workpiece is analyzed. The influence of the kinematic components of the longitudinal feed and cutting speed are not given.

At this time, scientists are creating new effective methods for grinding $[4,5,7]$.

Method [4] is implemented on an industrial equipment of the company in achieving good results of both productivity and quality of machining and low tool wear. The company does not provide grinding modes.

In $[5,6]$ there is a description of a new effective method for grinding in process control due to the angular relative orientation of the circle. However, information on how to choose the modes of the grinding process is not provided.

A new efficient method [7] for multi-pass deep grinding of stepped shafts with a conical end surface of a cup abrasive wheel, which can be implemented on domestic equipment, has been developed. The method provides an increase in the size of the contact and the projection of the relative feed rate in the direction of the normal $V_{n}$, so the processing performance is determined from equation [10]

$$
Q_{n}=\int_{F} V_{n} \cdot d F
$$

where $F, d F$ are the contact area and its element. 
Expression (1) relates and prioritizes between process intensity parameters, in this case for grinding.

The method allows obtaining a roughness of the processed surface in the form of a grid [11, 12]. The heat load as it approaches the forming point in the passages decreases slightly, due to the reduction of the contact area width.

In the joint work by the authors [13] the functional dependence of the relative speed of circular feed in the direction of the normal $V n$ (normal speed) for the case of processing by the method for longitudinal deep grinding with an oriented tool is determined. Its influence on processing productivity is analyzed.

According to the authors, it is the lack of equations, by definition, $V n$ in its explicit functional form that does not allow using widely the normal rate, as an indicator of the intensity of the grinding process.

The equations of mathematical models of the circle surface and the formation function are given [12], which are written through the product of matrices of linear and angular displacements [10, 14]

$$
\vec{r}(\theta, z)=A^{6}(\theta) \cdot A^{1}(R(z)) \cdot A^{3}(z) \cdot \vec{e}^{4},
$$

where $A^{1}(q), A^{2}(q), A^{3}(q)$ is the matrix of linear displacement along the axes $x, y, z ; A^{4}(q), A^{5}(q), A^{6}(q)$ is the matrix angular rotations relative to the axes $x, y, z$; q is a generalized coordinate; $R(z)$ is radial position of the point running along the surface of the tool as a function of longitudinal coordinate $z ; \theta$ is an angular parameter that corresponds to the position of a point that runs.

The ort of the normal to the tool surface $r(\theta, z)$ of rotation of the grinding wheel at the point $e^{4}$ that runs along the surface of the tool is determined from the expression [15]

$$
\vec{n}(\theta)=\left[\begin{array}{lll}
\cos \theta \cdot \sin \alpha & \sin \theta \cdot \sin \alpha & \cos \alpha
\end{array}\right]^{T},
$$

where $\theta, z$ are curvilinear coordinates [15].

The angle $\alpha$ is formed during wear due to different loads of the profile sections.

In view of the smallness of the angles $\theta$ and $\alpha$, the coordinates of the vector are considered equal $\vec{n}(\theta)=\left[\begin{array}{lll}\alpha & 0 & 1\end{array}\right]^{T}$.

Valid values for the projection of the relative velocity to normal, the relationship between specific performance and contact length are found.

The mode parameters for the methods for longitudinal and mortise grinding are determined. For mortise grinding, all sections of the profile work in the same conditions, and the size of the contact and the effect of the feed cut on the normal speed are much larger, which causes a high value of grinding productivity.

Specific performance is the integral average figure that varies both in the plane of rotation and height of the circle [10]. Different load leads to a different wear profile. Therefore, in addition to the specific productivity, instantaneous and average productivity is sometimes used. The cutting processes according to the specific processing capacity and the intensity is also divided into rough (or previous) and finishing ones [8]. For intensive cutting modes there the most loaded lane appears close to the border of the contact area, where the product of vectors $V_{n}$ of the relative velocity and the normal takes maximum values.

As an indicator of the intensity of the treatment, instead of the specific performance the projection of feed rate on normal of the circle surface is used that contains local information. This will allow unifying the choice of cutting modes, including new and promising techniques for grinding, distinguishing counter and associated processing with other parameters being the same as well.

Among the common methods for grinding, as a reference for comparison, it is possible to adopt the method for cutting, due to its high productivity, due to the large size of the contact, and the same working conditions along the entire profile of the tool.

In the work by the author [16], it is proposed to use the relative velocity in the normal direction - the normal speed as a new local indicator of intensity of a grinding process.

The normal velocity $V_{n}$ is the best characteristic of the intensity of the process, as it contains information about the load of each separate parcel within contact and account for all kinematic components. This product of $V_{n}$ allows considering the relative feed direction as to the cutting speed (passing or counter). Normal speed is rapidly increasing and becomes maximum allowed values only in the narrow, most loaded strip, which is located near the border of the contact. By the intensity, its meaning is distinguished from the fine or finish machining [1]. At the same time, the majority of contact can be almost never loaded.

Taking into account all the kinematic components of the longitudinal and circular mortise grinding, the tool profile can be divided into the following sections: the peripheral, end face (cuts the basic allowance), and transitional (conjugates the above areas and is formed during wear and editing).

It is proved that the cross product $V_{n}$ contains the full local information about the work of each individual parcel within contact and account for all kinematic components. If the cutting speeds and projections $V_{n}$ on the normal direction are the same for different methods, then the distances between adjacent cutting surfaces will be the same.

In the joint work of the authors [17], among the parameters of the cutting process, the intervals between the moments of neighboring contacts are defined.

This allows you to provide a set of values: the product of the time interval between the contacts of the cutting edges (or blades) at normal speed and the cutting speed of the physical sense, which is the thickness of the cut layer (Fig. 1)

$$
A_{z}\left(V_{n}, V_{k r}\right)=\Delta_{\tau}\left(V_{n}, V_{k r}\right) \cdot V_{n} .
$$

If for different processing methods and cutting speeds the cut thicknesses are the same, then such modes can be considered equivalent.
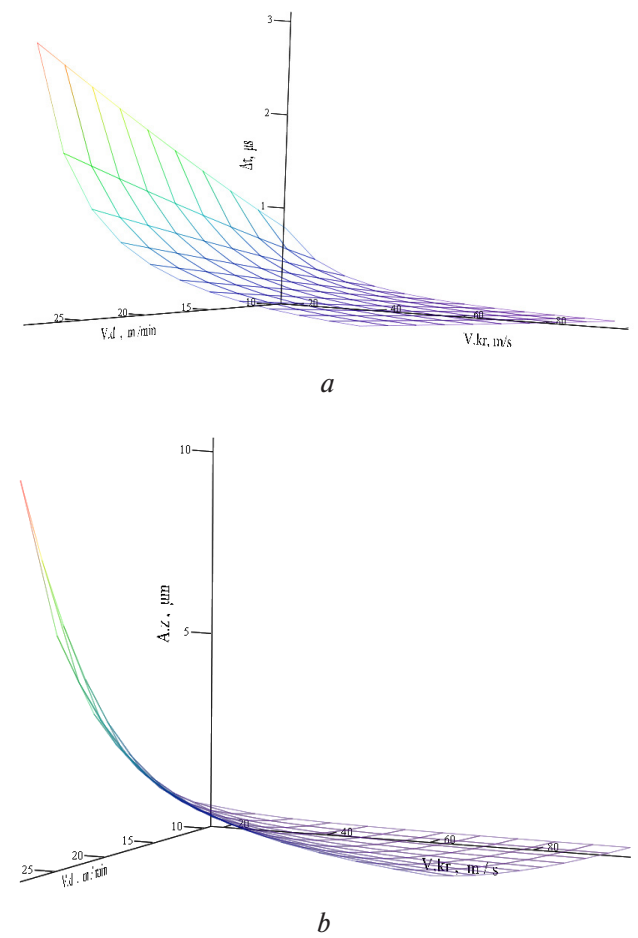

Fig. 1. The influence of modes $(V n, V k r)$ on the time intervals between contacts (a) and the thickness of the slices (b) for counter grinding [17] 
At the same time, the indicator $V_{n}$ allows distinguishing between the processes of associated and counter processing at the same limits of contact and the value of specific productivity. For such processes, the temperature differs significantly.

The analyzed dependence of the thickness on the cutting speed does not contradict the experimental data on the study on the cutting thickness [17].

The established relationship between the normal speed $V_{n}$ and the specific productivity allowed distinguishing between the processes for counter and associated grinding, which affects the thermal stress.

Unsolved aspects of the problem. The search for new processing methods [4, 5 and 7] requires finding the normal speed $V_{n}$ which is an actual problem. However, how one assigns the modes of new methods for grinding?

The use of vector products $V_{n}$ to reduce the amount of reference data makes them more versatile. The data can be used for methods for milling and grinding. Accordingly, one should design the tables of sensitive data.

The determined modes for methods of longitudinal and plunge grinding require improvement and generalization for other methods of cutting to reflect vertical flow.

However, the generalization of the mathematical function model of morphogenesis, in case of vertical movement and angular orientation, is not carried out. This model allows for the simplification of mathematical relations and provides them with clear meaning.

Purpose. A method for using a new measure of the intensity of cutting conditions to improve the efficiency of processes, which will reduce the amount of background information of methods for both grinding and processing by blade tool.

Technique. Analytical research studies are carried out. The results of calculations are analyzed. Conclusions are made.

Results. A new calculation scheme is proposed (Fig. 2), which includes the following movements: rotation of the circle and parts, and relative feeds: longitudinal $S_{p o z}$, transverse $S_{p o p}$ and vertical $S_{Y}$.

The diagram shows the formation of a fragment of a stepped roller with axes of the part crossed at an angle $\psi$ and the abrasive circle of a cup shape [10].

Through the small size of the contact area, it can be calculated using Euler radius of curvature $R_{e}=\frac{R}{\sin \psi}$, where $R$ is the radius of the tool.

Tool rotation for determining the position of the line contact which defines the shaping [13], can be ignored. It does not lead to a relative change in position of the part. The other movements - the rotation of the part at an angle $\varphi$ and its translational motion at a distance $p^{*} \varphi-$ have a kinematic rela-

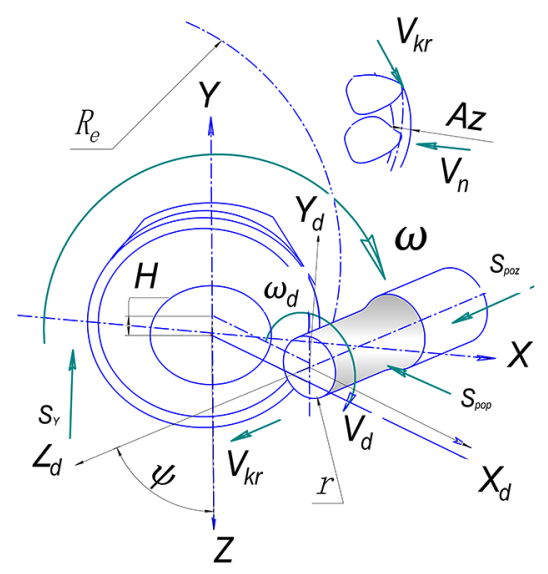

Fig. 2. Calculation scheme to determine the projection of the relative velocity to normal $V_{n}$ tionship with each other through the parameter of helical motion $p[10,14]$.

The process of feeding the material which is cut to sections of the instrument can be recorded through the forming function on the machine, transferring to the system of coordinates (SK) of part

$$
\begin{gathered}
\vec{r}(\theta, z, \varphi)=A^{1}(h \cdot \varphi) \cdot A^{3}(p \cdot \varphi) \cdot A^{6}(-\varphi) \cdot A^{4}(-v) \cdot \times \\
\times A^{1}(-R-r) \cdot A^{5}(\psi) \cdot A^{2}(H) \cdot \vec{r}(\theta, z),
\end{gathered}
$$

where $R, r$ are radii of the circle and part; $H$ is the vertical distance between the coordinate systems.

Differentiation by time (or angle $\varphi$ ) [15] of the radius-vector determines the relative velocity of the circle projected on the axis SK part

$$
\vec{V}(\theta, z, \phi)=\frac{\partial \vec{r}(\theta, z, \phi)}{\partial \phi},
$$

where $\omega_{d}=\frac{d \varphi}{d t}=2 \pi^{*} n_{d}, \quad n_{d}=V_{d} / r$ is the number of revolutions of the circular flow of part $V_{d}$

The feed per revolution, both cross-section (cut-in) and longitudinal, is determined using the appropriate steps $S_{p o p}=$ $=n_{d} \cdot X_{d} ; S_{p o z}=n_{d} \cdot Y_{d}$, or through parameters of a screw motion $p=\frac{Y_{d}}{2 \pi}: h=\frac{X_{d}}{2 \pi}$.

The normal vector, transferred in the SC part, has the same projection (given $\vec{n}_{d i}=L^{5}(\psi) \cdot \vec{n}$ ). Where $v$ is the angle between the axes of rotation of the circle and the part, where $L^{5}(\psi)$ is the matrix of size $3 \times 3$, formed from the matrix $A^{4}(v)$.

The scalar product of vectors does not depend on the angle $\varphi$ of rotation of the details, which can be checked directly. Therefore, the parameter $\varphi$ can be set to any value, for example $\varphi=0$, which simplifies calculations.

Expressions $(2,3)$ allow determining the rate of supply of the allowance $V_{n}$ to the parts of the tool, i.e. the intensity [10]

$$
V_{n}(\theta)=n_{d} \cdot\left\{2 \pi \cdot\left(R_{e}+r\right) \cdot \theta+\left(X_{d}+Y_{d} \cdot \alpha\right)\right\} .
$$

In the general case, with the available cross-section (cutin) and longitudinal feeds, local depth of the passage is determined by the total as

$$
t_{\Sigma}=X_{d}+Y_{d} \cdot \alpha=t_{\text {rad }}+t_{p o z},
$$

where $t_{r a d}$ and $t_{p o z}$ are respectively, the radial and longitudinal components of the depth.

In the first approximation, it is proposed to determine the angle $\alpha$ from the expression $\alpha=\frac{t_{\Sigma}}{2 Y_{d}}$.

The normal speed $V_{n}$ reaches the highest value at the interface in the plane of rotation of the circle, i. e. the largest value of contact angle $\theta=\theta_{n}$

$$
V_{n \max }=V_{n}\left(\theta_{n}\right) .
$$

The angular boundaries of the contact circle depend on: the intersections with the surface of the chip, $\theta_{2}$ and the position of the features [13] $\theta 1$, which is provided by (4) $V_{n}\left(\theta_{1}\right)=0$.

$$
\theta_{i}=\theta_{2}-\theta_{1}=\sqrt{\frac{2 r \cdot t_{\Sigma}}{R_{e} \cdot\left(R_{e}+r\right)}}-\left(-\frac{t_{\Sigma}}{2 \pi\left(R_{e}+r\right)}\right) .
$$

Expression (4) explains how the dimensions of the contact increase due to the transverse and longitudinal feeds, which causes an additional increase in the productivity of longitudinal and deep grinding.

Equations $(4,7)$ prove the influence of longitudinal and transverse feeds on productivity, which is neglected in theoretical dependences.

After substituting the boundaries of the contact angle and simplifications in $V_{n \max }$, we get 
Intensity parameters of round longitudinal grinding

\begin{tabular}{|c|c|c|c|c|c|c|c|c|c|}
\hline $\begin{array}{c}\text { Circular feed, } \\
\mathrm{m} / \mathrm{min}\end{array}$ & $\begin{array}{c}\text { The radii of the circle } \\
\text { and part, } \mathrm{mm}\end{array}$ & $\begin{array}{c}\text { Longitudinal feed } \\
\mathrm{mm} / \mathrm{rev}\end{array}$ & $\begin{array}{c}\text { Allowance, } \\
\mathrm{mm} / \mathrm{rev}\end{array}$ & $\begin{array}{c}\text { Rotated parts, } \\
\mathrm{s}^{-1}\end{array}$ & $\begin{array}{c}\text { Normal speed, } \\
\mathrm{mm} / \mathrm{s}\end{array}$ & $\begin{array}{c}\text { Specific productivity } \\
\mathrm{mm}^{2} / \mathrm{s}\end{array}$ & $\begin{array}{c}\text { Processing } \\
\mathrm{mode}^{\prime}\end{array}$ \\
\hline$V_{d}$ & $R$ & $r$ & $S_{p o z}$ & $t_{\mathrm{o}}$ & $n_{d}$ & $V_{n \max }$ & $Q_{p}^{S P}$ & $Q_{p}^{T}$ & \\
\hline 25 & 200 & 30 & 5 & 0.02 & 2.2 & 16.3 & 8.3 & 8.4 & finishing \\
\hline 20 & 200 & 30 & 2 & 0.02 & 1.8 & 13.1 & 6.7 & 6.7 & finishing \\
\hline 45 & 200 & 80 & 10 & 0.05 & 1.5 & 31.4 & 37.5 & 37.6 & draft \\
\hline 30 & 150 & 30 & 15 & 0.050 & 2.7 & 31.7 & 25.0 & 25.1 & draft \\
\hline 20 & 150 & 20 & 20 & 0.020 & 2.7 & 15.9 & 6.7 & 6.7 & finishing \\
\hline 50 & 150 & 80 & 24 & 0.025 & 1.7 & 25.8 & 20.8 & 20.9 & draft \\
\hline 50 & 300 & 150 & 28 & 0.015 & 0.9 & 14.4 & 12.5 & 12.5 & draft \\
\hline
\end{tabular}

$$
V_{n \cdot \max }=n_{d} \cdot\left(2 \cdot \pi \cdot \sqrt{2 \cdot r \cdot t_{\Sigma} \cdot\left(1+\frac{r}{R_{e}}\right)}+t_{\Sigma}\right) .
$$
$V_{n}$.

The specific productivity is associated with a normal speed

In a simplified way, it is defined [2]

$$
Q_{p}^{s p}=V_{d} \cdot t_{0}
$$

where $t_{o}$ is the allowance for the passage [8].

More precisely the determination is carried out taking into account the longitudinal and radial feeds, and using the expression (4), that is, the specific theoretical capacity is equal to

$$
\begin{gathered}
Q_{p}^{T}=\int_{\theta_{1}}^{\theta_{2}} V_{n}(\theta) \cdot R_{e} \cdot d \theta= \\
=n_{d} \cdot\left\{\left.\left(2 \cdot \pi \cdot R_{e} \cdot\left(R_{e}+r\right) \cdot \frac{\theta^{2}}{2}\right)\right|_{\theta_{1}} ^{\theta_{2}}+\left.t_{\Sigma} \cdot \theta\right|_{\theta_{1}} ^{\theta_{2}}\right\} .
\end{gathered}
$$

Here, the expression $R_{e} \cdot d \theta$ characterizes the element of the contact arc by length [15]

$$
L_{k}=\int_{\theta_{1}}^{\theta_{2}} R_{e} \cdot d \theta=\sqrt{2 \cdot \frac{r \cdot R_{e} \cdot t_{\Sigma}}{\left(R_{e}+r\right)}} .
$$

The effect of feed direction on the cutting speed is taken into account through the changing positions of the limits of the integral and the sign of angular velocity.

Expressions (8) and (10) can be solved simultaneously for conditions of longitudinal grinding, considering the limits of the contact. The result is

$$
Q_{p}^{T}=n_{d} \cdot t_{\Sigma} \cdot\left(2 \pi \cdot r+\sqrt{2 \cdot \frac{r \cdot R_{e} \cdot t_{\Sigma}}{\left(R_{e}+r\right)}}+\frac{\left(t_{\Sigma}{ }^{2}\right) \cdot R_{e}}{2 \cdot\left(R_{e}+r\right)}\right),
$$

or taking into consideration the smallness of the last term

$$
Q_{p}^{T} \approx n_{d} \cdot t_{\Sigma} \cdot\left(\pi \cdot d+L_{k}\right)
$$

The expression (13) takes into account both a circular flow (the first term) and the longitudinal and transverse (cut-in). It more accurately takes into account all kinematic components (column 9, Table 1).

In Table 1, the efficiency of the modes of longitudinal grinding are compared.

The conditions for the relationship between the intensity of the transverse (mortise) grinding are shown in Table 2. The similarity of the nature of the influence of longitudinal and transverse (cut-in) feeds according to (5) is considered as well as the greater contact length (11).

Let us analyze use of normal speed $V_{n}$ (4) to find the mode parameters of traditional and new promising grinding methods.
The use of normal speed does not contradict the existing recommendations for the choice of modes. Thus, according to equations $(8,12)$ an increase in $V_{d}$ by 2 times leads to a corresponding change in intensity with the same size, and the growth of $V_{n \text { max }}$ is behind on the depth $t_{\Sigma}(8)$.

Using the tables of standards of modes of grinding we can note that the circular feed, as the product of the number of turns on the radius part $r$, changes slightly with the same height values of the circle and the measure of roughness of the processing, which acts as a boundary condition.

The choice of operating parameters of multi-pass efficient grinding by new techniques [4] can be solved using line search methods for optimal solutions [18], where it is advisable to take the tool life as an objective function.

There is a generally accepted experimental dependence that characterizes the process of stability of the abrasive tool [1-3], which is considered as a power function of the grinding mode indicators

$$
T=\frac{C_{T}}{\left(Q \cdot K_{C}\right)^{n}} .
$$

Here $T$ depends on: the quality of the treated material $C t$ and rigidity of the technological system $-K C$. The exponent depends on the material, for steel, $n=1.5-1.7$. So the tool life is determined by the intensity of its use. This is true across

\begin{tabular}{|c|c|c|c|c|c|c|}
\hline 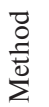 & $\begin{array}{c}V_{d}, \mathrm{~mm} / \mathrm{s} . \\
(\mathrm{m} / \mathrm{min})\end{array}$ & $\begin{array}{c}X_{d}, \\
(\mathrm{~mm} / \mathrm{rev})\end{array}$ & $\begin{array}{c}V_{n}, \\
\mathrm{~mm} / \mathrm{s}\end{array}$ & $\begin{array}{c}Q_{p}^{S P}, \\
\mathrm{~mm}^{2} / \mathrm{s}\end{array}$ & $\begin{array}{c}Q_{p}^{T}, \\
\mathrm{~mm}^{2} / \mathrm{s}\end{array}$ & $\frac{{ }^{*} \tilde{e}}{\frac{0}{0}}$ \\
\hline \multirow[b]{2}{*}{ Uี } & $\begin{array}{l}500 \div 800 \\
(20 \div 50)\end{array}$ & $0.0025-0.075$ & $>20$ & $15-50$ & $>10$ & D \\
\hline & $\begin{array}{l}330 \div 600 \\
(20 \div 40)\end{array}$ & $0.001-0.005$ & $<20$ & $1-15$ & $<10$ & F \\
\hline \multirow{2}{*}{ 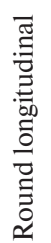 } & $\begin{array}{l}200 \div 400 \\
(12 \div 25)\end{array}$ & $0.01-0.025$ & $>20$ & $15-50$ & $>10$ & D \\
\hline & $\begin{array}{l}250 \div 920 \\
(15 \div 55)\end{array}$ & $0.005-0.015$ & $<20$ & $1-15$ & $<10$ & $\mathrm{~F}$ \\
\hline
\end{tabular}
both traditional and advanced methods.

Durability $T$ depends only on the normal velocity $V_{n}$, which is a comprehensive measure, and at the same time characterizes the specific capacity that determines the balance

Table 2

Characteristics of the grinding mode intensity, taking into account the longitudinal and transverse feeds

Note: * D - draft, F - finishing 
condition. The boundary condition that limits the mode parameters is the achievement of the roughness of the treated surface. As the number of revolutions of the part and, accordingly, the passages above it $K=H / S_{0}$ increases, ( $H$ is the height of the circle), the roughness parameter decreases [11, 19].

It is known [3] that the following conditions for a single variable $V n$ are possible only at the maximum values, which provides both stability and productivity, therefore

$$
T\left(\frac{1}{V_{n}}\right) \rightarrow \max , \quad\left(V_{n}\right)_{T}=V_{n}^{\text {chorn }} \rightarrow \max .
$$

The value obtained $\left(V_{n}\right)_{T}$ according to formula (10) defines the performance parameters $n_{d}$ and $t_{\Sigma}$

So, the grinding modes in the prospectus of the company Juncker [4] do not specify. However, from experience of their use it is known that a high durability with low wear of the circle is provided.

How one selects the modes for promising new ways of grinding [4, 5 and 7$]$ ?

If you increase the speed details $n_{d}$, or circular feed that acts as a boundary condition the value of the parameter of screw motion, depth per pass $t_{\Sigma}$, and the contact angle, i.e. decrease simultaneously

$$
\left.\begin{array}{l}
\left(V_{n}\right)_{T}=\text { const } \\
n_{d} \uparrow
\end{array}\right\} \Rightarrow \begin{aligned}
& Y_{d}=\frac{S_{p o z}}{n_{d}} \downarrow \\
& t_{\Sigma}=\frac{t}{n_{d}} \downarrow \\
& \theta_{n} \downarrow
\end{aligned} .
$$

Given (8), we receive an indicator of the effectiveness of the grinding method $V_{n \max }$. Here $R_{e}=R / \sin \alpha_{\mathrm{kr}}$ - Euler curvature radius of the working cone of the tool, which has large values [15]; $\sin \alpha_{k r}$ is the angle between the section of the profile of the circle (or tangent to it) and the plane of rotation.

Therefore, the effect of high speeds of the part on the growth of normal speed can be reduced by significantly reducing the diametrical dimensions of the tool and reducing the feed per revolution. This allows you to adhere to the specified stability of the tool and the quality of the treated surface.

Conclusions. Normal speed characterizes the intensity of the grinding mode more fully than the specific productivity. It contains local information and includes all kinematic components.

The equation for finding $V_{n \text { max }}(8)$ can be used to determine the modes of advanced grinding methods, taking into account the experience of well-studied methods of round longitudinal and transverse (cut-in) grinding.

The modes for different grinding methods can be considered equivalent if the normal speeds are the same for a given cutting speed. Therefore, the distances between adjacent cutting surfaces will also be the same.

The distance between adjacent cutting surfaces during rotation without loss of productivity can be reduced by simultaneously increasing the number of revolutions and minute feed, which is confirmed by the practice of the Quick point method (Germany) [4].

Reducing the depth of cut of the passage as it approaches the forming point will reduce the length of the contact, the wear of the profile within the forming area and the local temperature [17].

\section{References.}

1. Ryabenkov, I. A. (2018). Theoretical substantiation of technological possibilities of ordinary and intermittent grinding. Cutting and tools in technological systems, (89), 149-158.
2. Kundráka, N. K. J., Fedorovich, V., Pyzhov, I., Markopoulosc, A. P., \& Klimenkod, V. (2017). Theoretical Analysis of the Contact Area between Grinding Wheel Surface and Workpiece in Flat Face Grinding with Spindle Axis Inclination. Manufacturing Technology, 17(2), 203-210.

3. Klimenko, S.A., Kopeikina, M.Yu., Klimenko, S.A., \& Manokhin, A. S. (2016). The concept of improving the performance of cutting tools made of polycrystalline composites based on cubic boron nitride. Information technologies in education, science and industry, 2(13), 108-114.

4. Quickpoint (n.d.). All in one fix: [Prosp. "Junkermaschinen" company on machines "Quickpoint 1000", "Quickpoint 3000", "Quickpoint 4000"]. Nordrash, Germany, Retrieved from https://www.junker-group.com/ru/shlifovalnye-stanki/products/quickpoint/.

5. Kalchenko, V.I., Kalchenko, V.V., Sira, N. M., Kologoida, A. V., Kuzhelny, Ya. V., Kalchenko, D. V., ..., \& Aksonova, O. O. (2019 ). Patent of Ukraine No. 134080. Ukraine.

6. Kalchenko, V., Volodymyr Kalchenko, V., Kuzhelny, Ya., \& Morochko, V. (2019). Determination of cutting forces during finishing grinding of a cylindrical surface of a shaft. Technical sciences and technologies: scientific journal/Chernihiv National Technological University, 1(15), 41-52.

7. Rudyk, A.V., \& Rudyk, V.A. (2017). Patent of Ukraine No 117066. Ukraine IPC.

8. Seredenko, B. M., Zabolotniy, O.A., \& Orobchenko, A.P. (2016). Determination of cutting temperature during milling of titanium alloys with end mills. Bulletin of NTUU "KPI". Mechanical Engineering, 3(78), 71-76.

9. Tripasy P., \& Maity, K. P. (n.d.). Experimental Investigation during Micro-Milling of Hybrid Al6063 MMC Reinforced with $\mathrm{SiC}$ and $\mathrm{ZrO}_{2}$. Retrieved from https://www.scientific.net/ AEF.33.1

10. Pasov, G.V., Venzhega, V.I., \& Bakalov, V.G. (2019). Grinding of shaped surfaces on the VZ-208-F3 machine. Technical sciences and technologies: scientific journal/Chernihiv National Technological University, 2(16), 16-22.

11. Ropyak, L. Ya., \& Ostapovych, V. V. (2016). Investigation of the influence of diamond grinding modes on the roughness of the chrome coating by the method of mathematical planning of the experiment. Interuniversity collection "Scientific Notes", 53, 130-138.

12. Xing Shan Li, Mei Li Shao, Jun Wang, \& Yu Shan Lu. (n.d.). Simulation of the Surface Roughness by End Face Grinding Wheel with Ordered Abrasive Pattern. Retrieved from https://www.scientific.net/AMR.1095.898.12.

13. Rudik, A.V., \& Venzhega, V.I. (2015). Productivity of highly effective longitudinal and deep grinding of surfaces of rotation by periphery and end face of the oriented abrasive tool. Bulletin of Chernihiv State Technological University: Collection, 1(77), 59-64.

14. Larshin, V.P., Lishchenko, N. V., Ryabchenko, S. V., Nezhebovsky, V.V., \& Sereda, G.V. (2016). Profile grinding of gears with highly porous abrasive wheels. Equipment and tools for professionals, (5), 20-23.

15. Krivosheia, A. V., Storchak, M. G., Danilchenko, Yu. M., \& Ternyuk, N.E. (2015). Development of the concept, structure and principles of creation and functioning of a new technical system of synthesis of gears. Bulletin of NTU "KhPI", 34, 23-33.

16. Rudyk, A.V., Slednikova, O.S., Podzolkina, A.P., \& Kutsiy, O. L. (2016). Selection of modes of effective grinding of surfaces of rotation. Chernihiv National Technological University: Collection, 4(6), 62-70.

17. Rudik, A.V., \& Pasov, G.V. (2019). Dependence of cut parameters on modes at counter and passing grinding. "Scientific notes of Tavriya National University named after V.I. Vernadsky. Series: Technical Sciences“, 30(69), 7, 7-12.

18. Pen, R. Z. (2017). Statistical methods of modeling and optimization of technological processes. International Journal of Experimental Education, 2, 81-83. 
19. Lavrinenko, V. I., \& Solod, V. Yu. (2015). On the question of the functional action of technological media in abrasive treatment with wheels made of superhard materials. Cutting and tools in technological systems, (85), 171-184.

20. Saoubi, R. M., Axinte, D., Soo, S. L., Nobel, Ch., Attia, H., Kappmeyer, Gr., ..., \& Sim, W.-M. (2015). High performance cutting of advanced aerospace alloys and composite materials. CIRP Annals - Manufacturing Technology, 64(2), 557-580.

\section{Методика визначення показника ефективності процесу шліфування}

\author{
А. В. Рудик ${ }^{1}$, В. М. Чуприна ${ }^{1}$, Г. В. Пасов ${ }^{2}$, \\ B. I. Венжега ${ }^{2}$
}

1 - Державний науково-дослідний інститут випробування і сертифікації озброєння та військової техніки, м. Чернігів, Україна, е-mail: andrei.rudik@gmail.com

2 - Національний університет «Чернігівська політехніка», м. Чернігів, Україна

Мета. Створення методики використання нового показника інтенсивності режимів різання, що дозволить скоротити обсяг довідкової інформації за методами як шліфування, так і обробки лезовим інструментом.

Методика. Аналітичні дослідження.

Результати. Запропоновано новий локальний показник інтенсивності режимів різання, що має явний фізичний зміст - товщина зрізу. Вона визначається проекцією швидкості подачі деталі на напрямок нормалі до поверхні інструменту. Показник можна застосовувати для різної кінематики процесів шліфування деталей. Методика придатна для абразивного й лезвійного інструментів. Завдяки новому показнику скорочується обсяг довідкової інформації.

Наукова новизна. Як показник інтенсивності обробки замість інтегрального показника питомої продуктивності пропонується використовувати локальний - проекція швидкості відносного руху подачі в напрямку нормалі. Показник має чіткий фізичний зміст і визначає товщину зрізу для заданої швидкості різання. Він дозволяє врахувати всі кінематичні складові й містить повну інформацію про навантаження ділянки профілю в межах контакту, дозволяє розрізняти попутну і зустрічну обробку, що залежать від взаємного напрямку векторів швидкості різання та кругової подачі. Знайдено взаємозв'язок між проекцією швидкості відносного руху в напрямку нормалі, питомою продуктивністю й довжиною контакту.

Практична значимість. Визначено показник режимів ефективності шліфування для методів поздовжньої й виразної обробки деталей. Це дає можливість уніфікувати дані таблиць режимів, використовувати розрахунки як для різних методів шліфування, так і обробки лезовим інструментом. Запропонована методика визначення показника ефективності шліфування орієнтованим інструментом, де в якості цільової функції виступає стійкість. Продуктивність $€$ балансовою умовою, а шорсткість поверхні визначає граничну умову. Наведено визначення крайніх значень інтенсивності. Визначені окремі показники режиму для створеного як нового способу, так і того, що використовують на обладнанні відомої німецької фірми.

Ключові слова: режими шліфування, питома продуктивність, нормальна швидкість, кутовий розмір контакmy, стійкість

\section{Методика определения показателя эффективности процесса шлифования}

\author{
А. В. Рудик $\kappa^{1}$ В. М. Чуприна ${ }^{1}$, Г. В. Пасов ${ }^{2}$, \\ В.И. Венжега ${ }^{2}$
}

1 - Государственный научно-исследовательский институт испытаний и сертификации вооружений и военной техники, г. Чернигов, Украина, e-mail: andrei.rudik@ gmail.com

2 - Национальный университет «Черниговская политехника», г. Чернигов, Украина

Цель. Создание методики использования нового показателя интенсивности режимов резания для повышения эффективности процессов, который позволит сократить объем справочной информации методов как шлифовки, так и обработки лезвийным инструментом.

Методика. Аналитические исследования.

Результаты. Предложен новый локальный показатель интенсивности режимов резания, который имеет явный физический смысл - толщина среза. Она определяется проекцией скорости подачи детали на направление нормали к поверхности инструмента. Показатель можно применять для различной кинематики процессов шлифования деталей. Методика пригодна для абразивного и лезвийного инструментов. Благодаря новому показателю сокращается объем справочной информации.

Научная новизна. В качестве показателя интенсивности обработки вместо интегрального показателя удельной производительности предлагается использовать локальный - проекция скорости относительного движения подачи в направлении нормали. Показатель имеет четкий физический смысл и определяет толщину среза для заданной скорости резания. Он позволяет учесть все кинематические составляющие и содержит полную информацию о нагрузке участка профиля в пределах контакта, позволяет различать попутную и встречную обработку, которые зависят от взаимного направления векторов скорости резки и круговой подачи. Найдена взаимосвязь между проекцией скорости относительного движения в направлении нормали, удельной производительностью и длиной контакта.

Практическая значимость. Определен показатель режимов эффективности шлифования для методов продольной и врезной обработки деталей. Это дает возможность унифицировать данные таблиц режимов, использовать расчеты как для различных методов шлифовки, так и обработки лезвийным инструментом. Предложена методика определения показателя эффективности шлифования ориентированным инструментом, где в качестве целевой функции выступает стойкость. Производительность является балансовым условием, а шероховатость поверхности определяет граничное условие. Приведены определения крайних значений интенсивности. Определены отдельные показатели режима для созданного как нового способа, так и того, что используют на оборудовании известной немецкой фирмы.

Ключевые слова: режимы шлифования, удельная производительность, нормальная скорость, угловой размер контакта, стойкость

Recommended for publication by Ye.Yu. Sakhno, Doctor of Technical Sciences. The manuscript was submitted 22.02.20. 